\title{
Enhancement of Biocontrol Efficacy of Pichia carribbica to Postharvest Diseases of Strawberries by Addition of Trehalose to the Growth Medium
}

\author{
Lina Zhao ${ }^{1}$, Hongyin Zhang ${ }^{1}{ }^{1},{\text { Jun } \mathrm{Li}^{2}}^{2}$, Jinghua Cui ${ }^{3}$, Xiaoyun Zhang ${ }^{1}$ and Xiaofeng Ren ${ }^{1}$ \\ 1 College of Food and Biological Engineering, Jiangsu University, Zhenjiang 212013, Jiangsu, China; \\ E-Mails: linabobo0706@163.com (L.Z.); zhangxiaoyungu@126.com (X.Z.); \\ renxiaofeng@ujs.edu.cn (X.R) \\ 2 Institute of Life Sciences, Jiangsu University, Zhenjiang 212013, Jiangsu, China; \\ E-Mail: lij_023@163.com \\ 3 The Library, Jiangsu University, Zhenjiang 212013, Jiangsu, China; E-Mail: cuijing_hua@126.com \\ * Author to whom correspondence should be addressed; E-Mail: zhanghongyin126@126.com; \\ Tel.: +86-511-88780201; Fax: +86-511-88780201.
}

Received: 13 February 2012; in revised form: 2 March 2012 / Accepted: 19 March 2012 /

Published: 22 March 2012

\begin{abstract}
The effects of trehalose on the antagonistic activity of Pichia caribbica against Rhizopus decay and gray mold decay of strawberries and the possible mechanisms involved were investigated. The proteomic analysis and comparison of $P$. carribbica in response to trehalose was analyzed based on two-dimensional gel electrophoresis. The antagonistic activity of $P$. carribbica harvested from the culture media of NYDB amended with trehalose at $0.5 \%$ was improved greatly compared with that without trehalose. The PPO (Polyphenoloxidase) and POD (Peroxidase) activity of strawberries treated with $P$. carribbica cultured in the NYDB media amended with trehalose at $0.5 \%$ was higher than that of the strawberries treated with $P$. carribbica harvested from NYDB. The $\beta-1$, 3-glucanase activity of strawberries treated with $P$. carribbica cultured in the NYDB media amended with trehalose at $0.5 \%$ was also higher than that of the strawberries treated with $P$. carribbica harvested from NYDB and the control. Several differentially expressed proteins of $P$. carribbica in response to trehalose were identified in the cellular proteome, most of them were related to basic metabolism.
\end{abstract}


Keywords: Trehalose; Pichia caribbica; postharvest diseases; antagonistic activity; strawberries; differentially expressed proteins

\section{Introduction}

The shelf-life of the strawberries is very short because of the postharvest fungal decay, which results in serious economic losses to strawberries. Rhizopus decay caused by Rhizopus stolonifer (Ehrenb.: Fr) Vuill., and gray mold decay caused by Botrytis cinerea Pers.:Fr. are two of the most severe postharvest diseases of strawberries [1,2]. Synthetic fungicides are primarily used to control postharvest decay loss, however, a growing international concern over the often indiscriminate use of synthetic fungicides on food crops because of their possible harmful effects on human health [3]. So an urgent search for alternative control measures with good efficacy, low residues, little or no toxicity to non-target organisms, and no harmful on environment and human health was needed.

Microbial biocontrol agents have shown great potential as an alternative to synthetic fungicides for the control of postharvest decay of fruits and vegetables [4]. Several biological control agents are effective in reducing postharvest decay caused by Rhizopus stolonifer and Botrytis cinerea on strawberry [5-9]. However, like other non-fungicides means, currently all the biocontrol yeasts cannot reduce postharvest diseases as effectively as synthetic fungicides. So for biological control to be accepted as an economically viable option, the efficacy of antagonistic yeasts in controlling postharvest disease must be enhanced [10].

Many attempts have been investigated to enhance the efficacy of postharvest biocontrol yeasts, including manipulations in the physical and chemical environment during storage, use of mixed cultures, addition of low doses of fungicides in the microbial cultures, addition of salt additives in the microbial cultures, addition of nutrients and plant products in microbial cultures, use of the microbial cultures in association with physical treatments, use of the microbial cultures with other approaches/additives [11]. Besides these attempts above, inducing incubation of the antagonistic yeast has become a useful method to improve the control efficacy of the antagonistic yeast in these years. For example, Yu et al. [12] reported that amending with chitin in the culture media may greatly improve the antagonistic activity of $C$. laurentii, and our research team found that the antagonistic activity of Rhodotorula glutinis against Botrytis cinerea in strawberries could be enhanced by adding chitin in the culture [13].

Trehalose is a unique sugar capable of protecting biomolecules against environmental stress. It is a stable, colorless, odor-free and non-reducing disaccharide, and is widespread in nature. Trehalose has a key role in the survival of some plants and insects, termed anhydrobionts, in harsh environments, even when most of their water body is removed [14]. Trehalose has been found to be optimal in protecting enzymes, antibodies, liposomes and microorganisms, during drying and later storage [15-17]. Combined effects of endo- and exogenous trehalose on stress tolerance and biocontrol efficacy of two antagonistic yeasts was investigated, the result suggested that when adding trehalose in the culture medium, $C$. laurentii and $R$. glutinis resulted in the highest level of biocontrol efficacy against blue mold in apple fruit caused by Penicillium expansum Link [18]. 
Pichia caribbica is a strain of antagonistic yeast which was isolated from the soil sample of an unsprayed orchard by our research team, and showed control efficacy to postharvest diseases of apples and pears (unpublished data). However, to our knowledge there is no information concerning enhancement the biocontrol efficacy of $P$. caribbica to postharvest disease of fruits by addition of trehalose to the growth media. In addition to this, most published reports have demonstrated enhancement of biocontrol efficacy of antagonistic yeasts through inducing incubation, but there is limited knowledge of the mode of action.

The objective of this study was to determine the influence of adding trehalose in the culture media on the efficacy of the P. carribbica in controlling postharvest Rhizopus decay and gray mold decay of strawberries and explore the possible physiological mechanisms involved. Besides, we used 2-DE followed by MALDI-TOF/TOF to investigate and analyze the biological function of the differently expressed proteins between the trehalose inducing incubation $P$. carribbica and the control $P$. carribbica in order to further explain the molecular mechanism of the biological process at proteomic level.

\section{Results and Discussion}

\subsection{Efficacy of P. carribbica Harvested from Different Media in Controlling of Rhizopus Decay and Gray Mold Decay of Strawberries}

All treatments with application of $P$. carribbica at $1 \times 10^{8}$ cells $/ \mathrm{mL}$ could reduce the disease incidence of Rhizopus decay of strawberries, compared with the control after 3 days of incubation at $20{ }^{\circ} \mathrm{C}(P<0.05)$ (Figure 1$)$. The antagonistic activity of $P$. carribbica was shown to be greatly enhanced through cultured in the NYDB media amended with $0.5 \%$ trehalose. The disease incidence of Rhizopus decay of strawberries treated with P. carribbica which were harvested from the media of NYDB amended with trehalose powder at $0.5 \%$ was $5 \%$, which was significantly lower than that of the control strawberries $(97.5 \%)$ and the strawberries treated with $P$. carribbica which were harvested from the media of NYDB (27.5\%). However, the antagonistic activity of $P$. carribbica was not enhanced through being incubated in the NYDB media amended with $0.2 \%$ or $0.8 \%$ trehalose, or NYTB media, compared with that incubated in NYDB without trehalose.

All treatments with application of $P$. carribbica at $1 \times 10^{8}$ cells $/ \mathrm{mL}$ could reduce the disease incidence of gray mold decay of strawberries, compared with the control after 3 days of incubation at $20{ }^{\circ} \mathrm{C}(P<0.05)$ (Figure 2). The disease incidence of gray mold decay of strawberries treated with $P$. carribbica which were harvested from the media of NYDB amended with trehalose at $0.2 \%, 0.5 \%$, $0.8 \%$ or $1 \%$ was significantly lower than the strawberries treated with $P$. carribbica which were harvested from the media of NYDB (45\%), especially when amended with trehalose at $0.5 \%(12.5 \%)$. 
Figure 1. Efficacy of $P$. carribbica harvested from different media in controlling of Rhizopus decay of strawberries. Fruit treatments are as follows: sterile distilled water $(\mathrm{CK})$, $P$. carribbica harvested from the media of NYDB (NYDB), $P$. carribbica harvested from NYDB amended with trehalose at $0.2 \%(0.2), P$. carribbica harvested from NYDB amended with trehalose at $0.5 \%(0.5), P$. carribbica harvested from NYDB amended with trehalose at $0.8 \%(0.8), P$. carribbica harvested from NYTB (NYTB). Bars represent standard errors. Data in columns with different letters are statistically different according to Duncan's multiple range test at $P=0.05$.

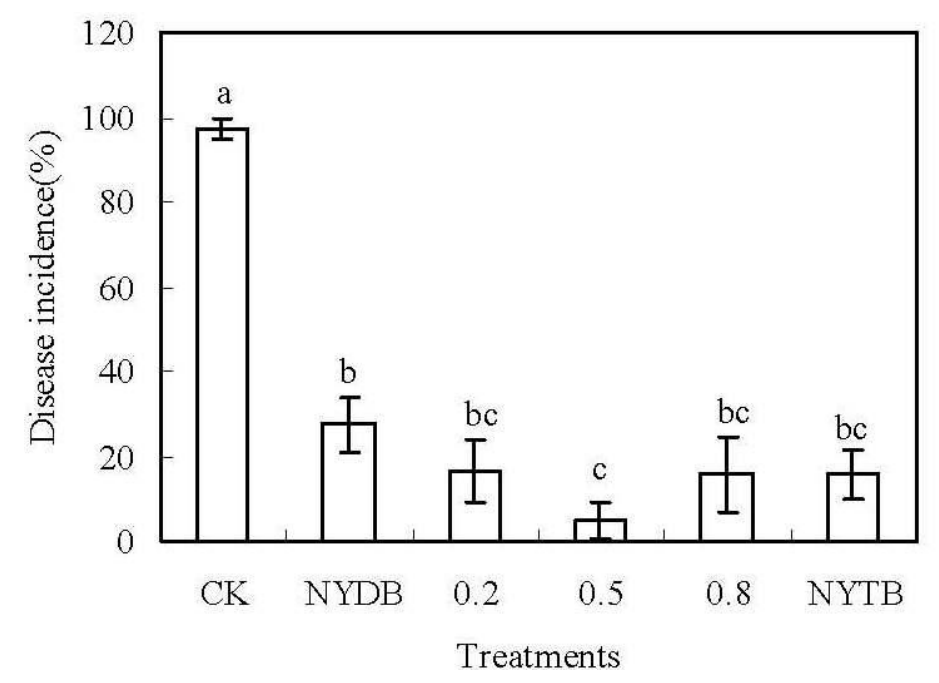

Figure 2. Efficacy of $P$. carribbica harvested from different media in controlling of gray mold decay of strawberries. Fruit treatments are as follows: sterile distilled water (CK), $P$. carribbica harvested from the media of NYDB (NYDB), $P$. carribbica harvested from NYDB amended with trehalose at $0.2 \%(0.2), P$. carribbica harvested from NYDB amended with trehalose at $0.5 \%(0.5), P$. carribbica harvested from NYDB amended with trehalose at $0.8 \%$ (0.8), P. carribbica harvested from NYTB (NYTB). Bars represent standard errors. Data in columns with different letters are statistically different according to Duncan's multiple range test at $P=0.05$.

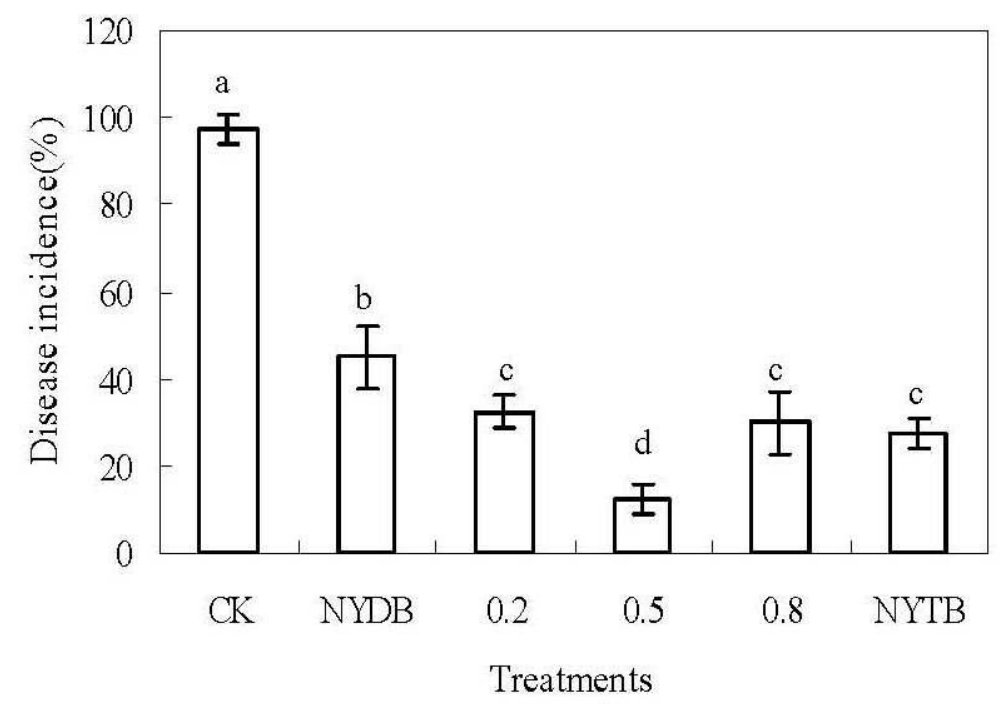


These results showed that $P$. carribbica has control efficacy to postharvest Rhizopus decay and gray mold decay of strawberries. Besides, the biological control activity of P. carribbica against Rhizopus decay and gray mold decay of strawberries was greatly enhanced when the yeast was harvested from the culture media of NYDB amended with $0.5 \%$ trehalose, compared with the case that $P$. carribbica harvested from NYDB without trehalose. Since that trehalose has no risks to humans and to the environment (it has been approved as a health food by FDA), and many tests approved that trehalose is non-toxicity, besides trehalose is a cheap and widely available natural resource [19], the utilization of trehalose might be an effective, safe and economic approach to enhance the biocontrol efficacy of P. carribbica.

\subsection{Effects of P. carribbica Harvested from Different Media on PPO, POD and $\beta$-1,3-glucanase Activities of Strawberries}

The PPO activities of strawberries treated with $P$. carribbica harvested from NYDB or NYDB amended with trehalose at $0.5 \%$ or the control increased gradually, and then began to decrease (Figure 3). The PPO activities of strawberries treated with P. carribbica harvested from NYDB or NYDB amended with trehalose at $0.5 \%$ were higher than that of the control at all the storage time. There was no significant difference between the PPO activity of strawberries treated with $P$. carribbica harvested from NYDB amended with trehalose at $0.5 \%$ and that of the strawberries treated with P. carribbica harvested from NYDB without trehalose at 1 and 2 days. However, the PPO activity of strawberries treated with $P$. carribbica harvested from NYDB amended with trehalose at $0.5 \%$ was higher than that of the strawberries treated with $P$. carribbica harvested from NYDB without trehalose at 3 days.

Figure 3. Effects of $P$. carribbica harvested from different media on PPO activity of strawberries. Fruit treatments are as follows: sterile distilled water $(\mathrm{CK}), P$. carribbica harvested from the media of NYDB (NYDB), and $P$. carribbica harvested from NYDB amended with trehalose at $0.5 \%(0.5 \%)$. Bars represent standard errors.

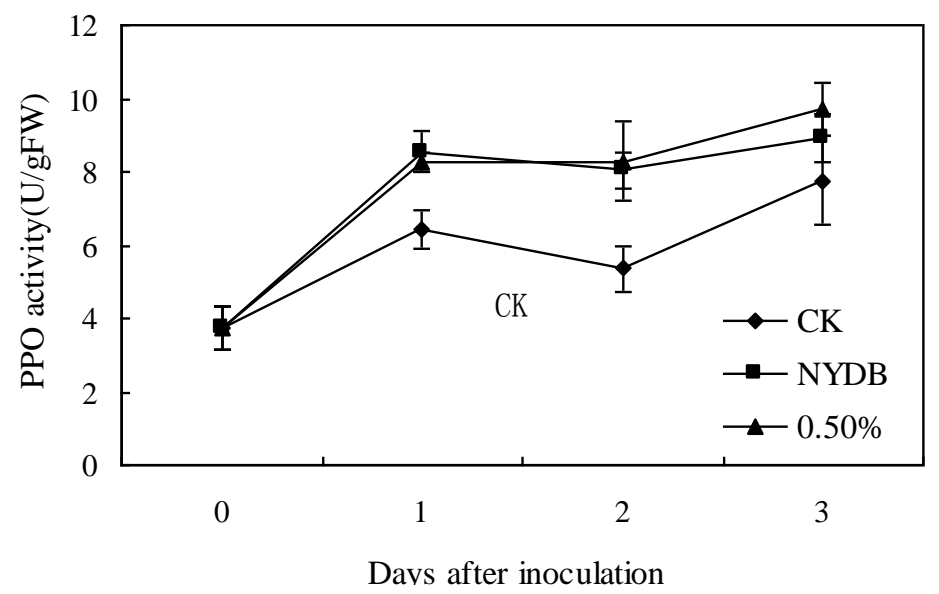

The POD activities of strawberries treated with $P$. carribbica harvested from NYDB or NYDB amended with trehalose at $0.5 \%$ or the control gradually increased, the POD activity reached the highest peak at 2 days, and then began to decrease at 3 days (Figure 4). The POD activity of 
strawberries treated with $P$. carribbica either cultured in NYDB media amended with trehalose at $0.5 \%$ or cultured in NYDB without trehalose were higher than that of the control at 2 days after storage, and the POD activity of the strawberries treated with $P$. carribbica cultured in the NYDB media amended with trehalose at $0.5 \%$ were higher than that of the strawberries treated with $P$. carribbica cultured in NYDB without trehalose at 2 days after storage.

Figure 4. Effects of $P$. carribbica harvested from different media on POD activity of strawberries. Fruit treatments are as follows: sterile distilled water (CK), P. carribbica harvested from the media of NYDB (NYDB), and P. carribbica harvested from NYDB amended with trehalose at $0.5 \%(0.5 \%)$. Bars represent standard errors.

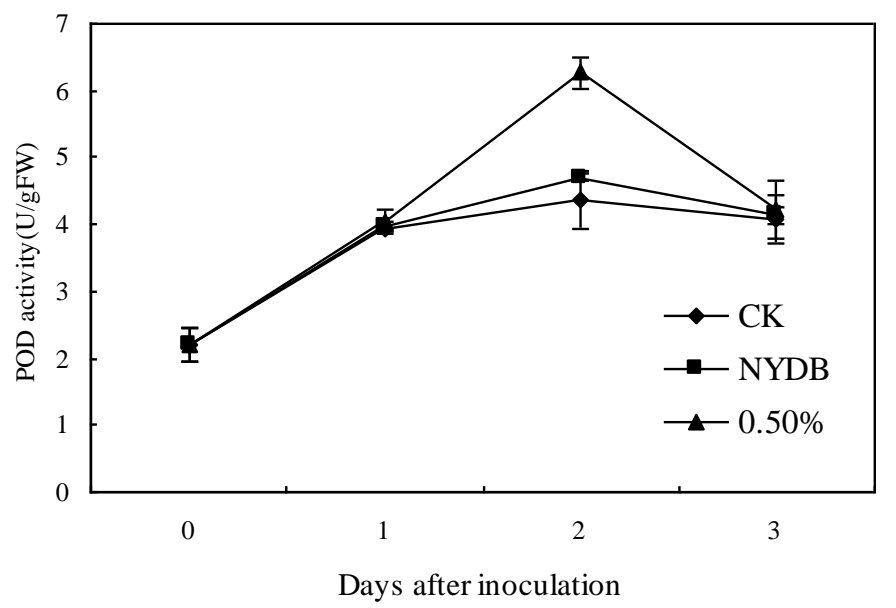

The $\beta$-1,3-glucanase activity of strawberries treated with $P$. carribbica harvested from NYDB and water increased quickly at the first day, and began to decrease at 2 days (Figure 5). However, the $\beta-1$, 3-glucanase activity of strawberries treated with $P$. carribbica harvested from NYDB amended with trehalose at $0.5 \%$ increased quickly at the first day and the second day, and began to decrease after 2 days. The $\beta$-1,3-glucanase activities of strawberries treated with $P$. carribbica harvested from NYDB and NYDB amended with trehalose at $0.5 \%$ were higher than that of the control strawberries at 1 day, and the $\beta$-1,3-glucanase activities of strawberries treated with $P$. carribbica harvested from NYDB amended with trehalose at $0.5 \%$ was higher than that of the control strawberries and the strawberries treated with $P$. carribbica harvested from NYDB at 2 days.

Polyphenoloxidase (PPO) catalyzes the oxidation of phenolics to quinines, which are more toxic to pathogens than the former [20]. Increased PPO activity is correlated with disease resistance in plants [21,22]. Peroxidases (POD) as bifunctional enzymes, can oxidize various substrates in the presence of $\mathrm{H}_{2} \mathrm{O}_{2}$, but also produce reactive oxygen species [23]. High POD activity is associated with the onset of induced resistance, which involves in several plant defence mechanisms, such as lignification and suberization $[24,25]$. The results showed that the PPO activity of strawberries treated with $P$. carribbica either cultured in the NYDB media amended with trehalose at $0.5 \%$ or cultured in NYDB without trehalose were higher than that of the control at all the storage time, and the POD activity of strawberries treated with $P$. carribbica either cultured in the NYDB media amended with trehalose at $0.5 \%$ or cultured in NYDB without trehalose were higher than that of the control at some storage time. What's more, the PPO and POD activity of strawberries treated with $P$. carribbica 
cultured in the NYDB media amended with trehalose at $0.5 \%$ was higher than that of strawberries treated with $P$. carribbica harvested from NYDB at some of the storage time. These results suggest that treatment of $P$. carribbica can enhance lignification and suberization of strawberries, which are related to maintenance of integrity and vital functions of the cell, and increase the levels of antimicrobial phenolic compounds, so that result in improvement of disease resistance. Moreover, adding $0.5 \%$ trehalose in the media can enhance this activity of $P$. carribbica to improve disease resistance of fruits. This may be one mechanism by which adding trehalose in the culture medium enhances the biocontrol efficacy of P. carribbica to postharvest Rhizopus decay and gray mold decay of strawberries.

Figure 5. Effects of $P$. carribbica harvested from different media on $\beta$-1,3-glucanase activity of strawberries. Fruit treatments are as follows: sterile distilled water (CK), $P$. carribbica harvested from the media of NYDB (NYDB), and P. carribbica harvested from NYDB amended with trehalose at $0.5 \%(0.5 \%)$. Bars represent standard errors.

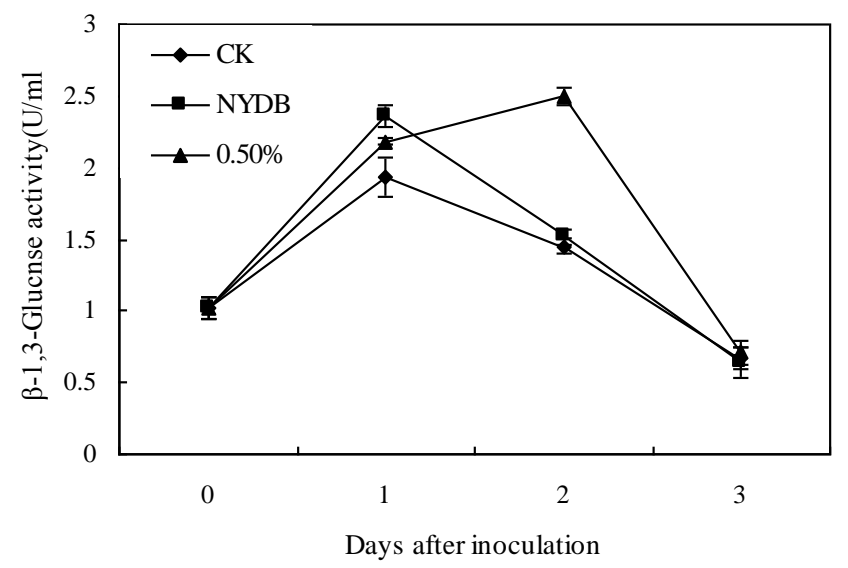

Our study displayed that $P$. carribbica either cultured in the NYDB media amended with trehalose at $0.5 \%$ or cultured in NYDB without trehalose induced more $\beta$-1,3-glucanase activity of strawberries compared with the control at some of the storage time, and $P$. carribbica cultivated in NYDB media amended with trehalose at $0.5 \%$ induced more $\beta$-1,3-glucanase activity of strawberries compared with $P$. carribbica cultured in the NYDB at some of the storage time. A previous study indicates that in plants, invasion by a pathogen induces the production of pothogenesis-related (PR) proteins, such as $\beta$-1,3-glucanases, and the putative role of $\beta$-1,3-glucanases in disease resistance is related to their capacity to degrade fungal cell wall, mainly composed of $\beta$-1,3-glucan [26]. This induction can be enhanced by some elicitors with the improvement of resistance to pathogens in plants [27,28]. Therefore, we infer that improving the activity of antagonistic yeast to induce the production of pothogenesis-related (PR) proteins of strawberries may be another reason that a more remarkable upward trend was seen in the efficacy of $P$. carribbica cultivated in the NYDB media amended with $0.5 \%$ trehalose in controlling postharvest decay of strawberries than the case in NYDB.

\subsection{Identification of Differentially Expressed Proteins}

For protein identification by means of peptide mass fingerprints (PMF), we used MASCOT to search protein database of Viridiplantae. More than 180 protein spots were detected in each gel after 
ignoring very faint spots and spots with undefined shapes and areas using Image Master 2D Elite software (Figure 6). A total of 78 proteins were differentially expressed when the yeast antagonist $P$. carribbica were harvested from the NYDB amended with trehalose at $0.5 \%$. Of the 78 proteins, 53 proteins were up-regulated and 25 proteins were down-regulated. Our test focuses on 46 kinds of differences in degree of peak protein (Table 1). Of all the differentially expressed proteins identified, most of them related to basic metabolism. This indicated that the basic metabolism of $P$. carribbica was improved by trehalose induced incubation, so as to improve its biocontrol efficacy to postharvest diseases of strawberries. Response patterns of $P$. carribbica to trehalose inducing incubation are complex, as the differentially abundant proteins are involved in multiple metabolic pathways.

Figure 6. Two-dimensional pattern of intracellular proteins of $P$. carribbica after cultivation in NYDB or NYDB amended with $0.5 \%$ trehalose powder.

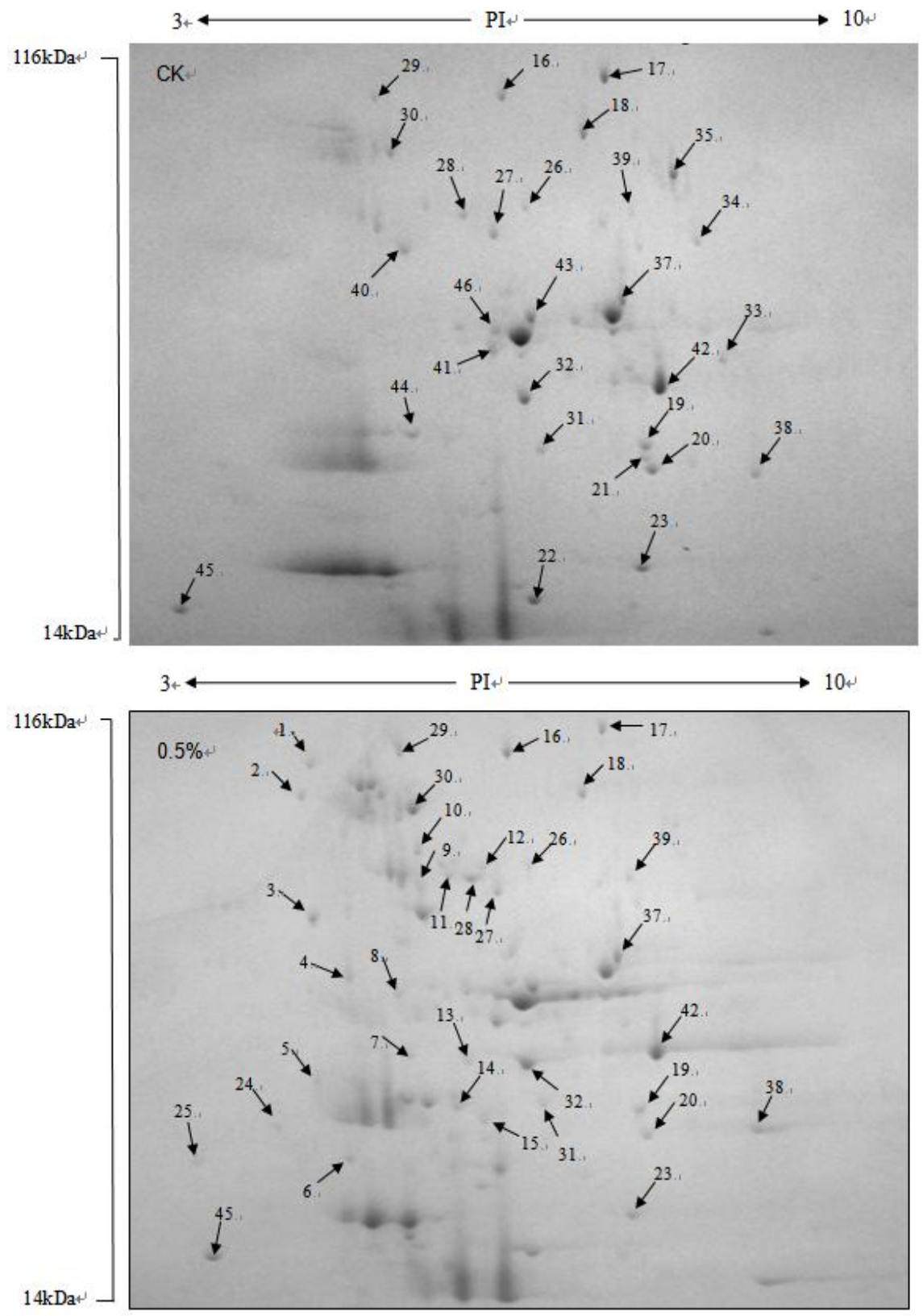


Table 1. Identification of cellular proteins of $P$. carribbica showing differential expression under trehalose cultivation using MS/MS analysis.

\begin{tabular}{|c|c|c|c|c|c|c|}
\hline Spot & Protein name & NCBI accession & Mass & PI & Species & Score \\
\hline 1 & 50S ribosomal protein & gi|116495724 & 12511 & 4.54 & Lactobacillus casei ATCC 334 & 66 \\
\hline 2 & $\begin{array}{l}\text { UDP-galactopyranose } \\
\text { mutase }\end{array}$ & gi|326332321 & 45474 & 5.11 & Nocardioidaceae bacterium Broad-1 & 68 \\
\hline 3 & $\begin{array}{l}\text { extracellular solute-binding } \\
\text { protein }\end{array}$ & gi|148546296 & 45335 & 6.02 & Pseudomonas putida $\mathrm{F} 1$ & 62 \\
\hline 4 & $\begin{array}{l}\text { eukaryotic initiation factor } \\
4 \mathrm{~A}\end{array}$ & gi|146422477 & 44615 & 4.91 & Meyerozyma guilliermondii ATCC 6260 & 100 \\
\hline 5 & predicted protein & gi|145345294 & 42354 & 9.84 & Ostreococcus lucimarinus CCE9901 & 65 \\
\hline 6 & $\begin{array}{l}\text { hypothetical protein } \\
\text { SCHCODRAFT_38806 }\end{array}$ & gi|302688397 & 10646 & 4.25 & Schizophyllum commune $\mathrm{H} 4-8$ & 51 \\
\hline 8 & elongation factor $\mathrm{Tu}$ & gi|587590 & 43823 & 5.06 & Wolinella succinogenes & 75 \\
\hline 9 & $\begin{array}{l}\text { electron transfer } \\
\text { flavoprotein subunit beta }\end{array}$ & gi|162447962 & 29409 & 8.87 & Acholeplasma laidlawii PG-8A & 69 \\
\hline 10 & $\begin{array}{l}\text { hypothetical protein } \\
\text { bthur0013_57560 }\end{array}$ & gi|228911633 & 45801 & 6.33 & Bacillus thuringiensis IBL 200 & 62 \\
\hline 11 & HNH nuclease & gi|220919264 & 38869 & 9.73 & Anaeromyxobacter dehalogenans $2 \mathrm{CP}-1$ & 65 \\
\hline 12 & $\begin{array}{l}\text { hypothetical protein } \\
\text { PGUG_04322 }\end{array}$ & gi|146415246 & 69936 & 5.30 & Meyerozyma guilliermondii ATCC 6260 & 71 \\
\hline 13 & $\begin{array}{l}\text { hypothetical protein } \\
\text { bcere0017_55820 }\end{array}$ & gi|229119349 & 28408 & 8.55 & Bacillus cereus Rock1-3 & 67 \\
\hline 14 & $\begin{array}{l}\text { hypothetical protein } \\
\text { PGUG_00294 }\end{array}$ & gi|146421948 & 35820 & 5.22 & Meyerozyma guilliermondii ATCC 6260 & 104 \\
\hline 15 & xylose reductase & gi|4103055 & 36076 & 5.58 & Meyerozyma guilliermondii & 66 \\
\hline 16 & $\begin{array}{l}\text { conserved hypothetical } \\
\text { protein }\end{array}$ & gi|146421560 & 84405 & 5.92 & Meyerozyma guilliermondii ATCC 6260 & 90 \\
\hline 17 & $\begin{array}{l}\text { conserved hypothetical } \\
\text { protein }\end{array}$ & gi|146420955 & 85681 & 5.68 & Meyerozyma guilliermondii ATCC 6260 & 134 \\
\hline 18 & $\begin{array}{l}\text { hypothetical protein } \\
\text { CLOSCI_01190 }\end{array}$ & gi|167758847 & 66473 & 4.76 & Clostridium scindens ATCC 35704 & 68 \\
\hline 19 & translation elongation factor & gi|47176804 & 22272 & 5.46 & Meyerozyma guilliermondii & 68 \\
\hline 20 & $\begin{array}{l}\text { conserved hypothetical } \\
\text { protein }\end{array}$ & gi|146417765 & 34916 & 7.17 & Meyerozyma guilliermondii ATCC 6260 & 96 \\
\hline 21 & translation elongation factor & gi|47176804 & 22272 & 5.46 & Meyerozyma guilliermondii & 82 \\
\hline 22 & $\begin{array}{l}\text { Melibiase subfamily, } \\
\text { putative }\end{array}$ & gi|254503502 & 77433 & 5.48 & Labrenzia alexandrii DFL-11 & 86 \\
\hline 24 & $\begin{array}{l}\text { hypothetical protein } \\
\text { PGUG_05024 }\end{array}$ & gi|146414197 & 32004 & 7.77 & Meyerozyma guilliermondii ATCC 6260 & 80 \\
\hline 25 & unnamed protein product & gi|189054178 & 65980 & 7.62 & Homo sapiens & 87 \\
\hline 26 & hypothetical protein & gi|67601196 & 32428 & 9.67 & Cryptosporidium hominis TU502 & 63 \\
\hline 27 & $\begin{array}{l}\text { hypothetical protein } \\
\text { PGUG_02894 }\end{array}$ & gi|146418399 & 57751 & 5.57 & Meyerozyma guilliermondii ATCC 6260 & 89 \\
\hline
\end{tabular}


Table 1. Cont.

\begin{tabular}{|c|c|c|c|c|c|c|}
\hline 28 & $\begin{array}{l}\text { transcriptional regulator, } \\
\text { laci family }\end{array}$ & gi|315498361 & 34890 & 5.36 & Asticcacaulis excentricus CB 48 & 87 \\
\hline 29 & $\begin{array}{l}\text { nitrite and sulfite reductase } \\
4 \mathrm{Fe}-4 \mathrm{~S} \text { region }\end{array}$ & gi|118579082 & 23982 & 8.66 & Pelobacter propionicus DSM 2379 & 71 \\
\hline 30 & heat shock protein SSB1 & gi|146420661 & 66250 & 5.29 & Meyerozyma guilliermondii ATCC 6260 & 162 \\
\hline 31 & $\begin{array}{l}\text { cytochrome d ubiquinol } \\
\text { oxidase subunit III }\end{array}$ & gi|156973199 & 16378 & 4.72 & Vibrio harveyi ATCC BAA-1116 & 71 \\
\hline 32 & $\begin{array}{l}\text { FAD dependent } \\
\text { oxidoreductase }\end{array}$ & gi|225011369 & 41131 & 8.66 & Flavobacteria bacterium MS024-2A & 73 \\
\hline 33 & $\begin{array}{l}\text { PREDICTED: } \\
\text { uncharacterized } \\
\text { glycosyltransferase AER61- } \\
\text { like }\end{array}$ & gi|109036798 & 62132 & 6.39 & Macaca mulatta & 61 \\
\hline 34 & $\begin{array}{l}\text { hypothetical protein } \\
\text { KSE_48990 }\end{array}$ & gi|311898269 & 37649 & 8.94 & Kitasatospora setae KM-6054 & 48 \\
\hline 35 & isocitrate lyase & gi|146413757 & 61766 & 6.31 & Meyerozyma guilliermondii ATCC 6260 & 88 \\
\hline 36 & $\begin{array}{l}\text { conserved hypothetical } \\
\text { protein }\end{array}$ & gi|238064394 & 46346 & 11.42 & Micromonospora sp. ATCC 39149 & 78 \\
\hline 37 & DEHA2D06160p & gi|50420381 & 54282 & 5.68 & Debaryomyces hansenii CBS767 & 72 \\
\hline 38 & $\begin{array}{l}\text { glyceraldehyde-3-phosphate } \\
\text { dehydrogenase }\end{array}$ & gi|146419367 & 35717 & 6.60 & Meyerozyma guilliermondii ATCC 6260 & 82 \\
\hline 39 & $\begin{array}{l}\text { hypothetical protein } \\
\text { HMU03290 }\end{array}$ & gi|291276562 & 8800 & 9.70 & Helicobacter mustelae 12198 & 67 \\
\hline 40 & $\begin{array}{l}\text { conserved hypothetical } \\
\text { protein }\end{array}$ & gi|313836798 & 12685 & 6.31 & Propionibacterium acnes HL037PA2 & 78 \\
\hline 41 & possible gp16 protein & gi|227496471 & 16688 & 4.70 & Actinomyces urogenitalis DSM 15434 & 79 \\
\hline 42 & $\begin{array}{l}\text { conserved hypothetical } \\
\text { protein }\end{array}$ & gi|301168105 & 15154 & 9.27 & Bacteriovorax marinus $\mathrm{SJ}$ & 82 \\
\hline 43 & enolase 1 & gi|146415384 & 46951 & 5.42 & Meyerozyma guilliermondii ATCC 6260 & 84 \\
\hline 44 & $\begin{array}{l}\text { rod shape-determining } \\
\text { protein MreC, putative }\end{array}$ & gi|21673403 & 32080 & 9.73 & Chlorobium tepidum TLS & 86 \\
\hline 45 & $\begin{array}{l}\text { hypothetical protein } \\
\text { LVIS_1868 }\end{array}$ & gi|116334433 & 7652 & 5.55 & Lactobacillus brevis ATCC 367 & 85 \\
\hline 46 & enolase 1 & gi|146415384 & 46951 & 5.42 & Meyerozyma guilliermondii ATCC 6260 & 97 \\
\hline
\end{tabular}

\section{Experimental Section}

\subsection{Antagonist and Growth Conditions}

The yeast antagonist $P$. carribbica was isolated from soils of orchard (the central shoal of Yangtze River, Zhenjiang). Classical methods based on colony and cell morphologies were used for a preliminary characterization of the yeast [29]. Subsequently, sequence analysis of the 5.8S internal transcribed spacer (ITS) ribosomal DNA (rDNA) region was used to identify the yeast colony [30]. $P$. carribbica isolates were maintained at $4{ }^{\circ} \mathrm{C}$ on nutrient yeast dextrose agar (NYDA) medium containing $8 \mathrm{~g}$ nutrient broth, $5 \mathrm{~g}$ yeast extract, $10 \mathrm{~g}$ glucose and $20 \mathrm{~g}$ agar, in $1 \mathrm{~L}$ of distilled water. 
Liquid cultures of the yeast were grown in 250-mL Erlenmeyer flasks containing $50 \mathrm{~mL}$ of nutrient yeast dextrose broth (NYDB) which had been inoculated with a loop of the culture. Flasks were incubated on a rotary shaker at $180 \mathrm{rpm}$ at $28^{\circ} \mathrm{C}$ for $24 \mathrm{~h}$. Following incubation, cells were centrifuged at $6000 \times g$ for $10 \mathrm{~min}$ and washed twice with sterile distilled water in order to remove the growth medium. Cell pellets were re-suspended in sterile distilled water and adjusted to an initial concentration of $5 \times 10^{8}$ cells $/ \mathrm{mL}$. Then, $1 \mathrm{~mL}$ of the above-mentioned suspensions were added and cultivated in nutrient yeast dextrose broth (NYDB) or NYDB amended with trehalose powder at $0.2 \%$ (using $0.8 \%$ dextrose and $0.2 \%$ trehalose as the carbon source) or $0.5 \%$ (using $0.5 \%$ dextrose and $0.5 \%$ trehalose as the carbon source) or $0.8 \%$ (using $0.2 \%$ dextrose and $0.8 \%$ trehalose as the carbon source) or NYTB (trehalose as the sole carbon source instead of dextrose in the media of nutrient yeast dextrose broth) on a rotary shaker at $180 \mathrm{rpm}$ at $28{ }^{\circ} \mathrm{C}$ for $24 \mathrm{~h}$. Then the yeast cells were harvested by centrifuging at $6000 \times g$ for $10 \mathrm{~min}$ and were washed twice with sterile distilled water. The yeast cell was counted using a hemocytometer. Cell pellets were re-suspended in sterile distilled water and adjusted to an initial concentration of $1 \times 10^{8}$ cells $/ \mathrm{mL}$ for experiments.

\subsection{Fruits}

Strawberries (Fragaria ananassa Duch.) cultivars "fengxiang" were harvested early in the morning and rapidly transferred to the laboratory. Berries were sorted on the basis of size, ripeness and to remove any with the apparent injuries or infections.

\subsection{Pathogen Inoculum}

The pathogen Rhizopus stolonifer (Ehrenb.: Fr) Vuill. and Botrytis cinerea (Pers.:Fr.) were isolated from infected strawberries. The culture was maintained on potato dextrose agar (PDA: extract of boiled potatoes, $200 \mathrm{~mL}$; dextrose, $20 \mathrm{~g}$; agar, $20 \mathrm{~g}$ and distilled water, $800 \mathrm{~mL}$ ) at $4{ }^{\circ} \mathrm{C}$, and fresh cultures were grown on PDA plates before use. Spore suspensions were prepared by removing the spores from the sporulating edges of a 7-day old culture with a bacteriological loop, and suspending them in sterile distilled water. Spore concentrations were determined with a hemocytometer, and adjusted as required with sterile distilled water.

\subsection{Efficacy of P. carribbica Harvested from Different Media in Controlling of Rhizopus Decay and Gray Mold Decay of Strawberries}

The surface of strawberries was wounded with a sterile cork borer (approximately 3-mm-diameter and 3-mm-deep) and treated with $30 \mu \mathrm{L}$ of (1) the cell suspensions of $P$. carribbica $\left(1 \times 10^{8}\right.$ cells $\left./ \mathrm{mL}\right)$ which were harvested from the media of NYDB; (2) the cell suspensions of $P$. carribbica $\left(1 \times 10^{8}\right.$ cells $\left./ \mathrm{mL}\right)$ which were harvested from the media of NYDB amended with trehalose powder at $0.2 \%$; (3) the cell suspensions of $P$. carribbica $\left(1 \times 10^{8}\right.$ cells $\left./ \mathrm{mL}\right)$ which were harvested from the media of NYDB amended with trehalose powder at $0.5 \%$; (4) the cell suspensions of $P$. carribbica $\left(1 \times 10^{8}\right.$ cells $\left./ \mathrm{mL}\right)$ which were harvested from the media of NYDB amended with trehalose powder at $0.8 \%$; (5) the cell suspensions of $P$. carribbica $\left(1 \times 10^{8}\right.$ cells $\left./ \mathrm{mL}\right)$ which were harvested from the media of NYTB and (6) the sterile distilled water as the control. Three hours later, $30 \mu \mathrm{L}$ of $R$. 
stolonifer suspensions $\left(1 \times 10^{4}\right.$ spores $\left./ \mathrm{mL}\right)$ or B. cinerea suspensions $\left(1 \times 10^{5}\right.$ spores $\left./ \mathrm{mL}\right)$ were inoculated to each wound. After air-drying, the strawberries were stored in enclosed plastic trays to maintain a high relative humidity (about 95\%) and incubated at $20{ }^{\circ} \mathrm{C}$ for 3 days. The number of the infected fruit wounds was examined. There were three replicates per treatment and 20 fruits each replicate. All treatments were arranged in a randomized complete block design, and the experiment was conducted twice.

\subsection{Effects of P. carribbica Harvested from Different Media on PPO (Polyphenoloxidase), POD (Peroxidase) and $\beta$-1,3-glucanase Activities of Strawberries}

The surface of strawberries was wounded with a sterile cork borer (approximately 3-mm-diameter and 3-mm-deep) and treated with $30 \mu \mathrm{L}$ of a cell suspension of $P$. carribbica $\left(1 \times 10^{8}\right.$ cells $\left./ \mathrm{mL}\right)$ which were harvested from the media of NYDB or NYDB amended with trehalose powder at $0.5 \%$ (using $0.5 \%$ dextrose and $0.5 \%$ trehalose as the carbon source) after $24 \mathrm{~h}$ incubation. Treatment with sterile distilled water served as the control. After air-drying, the strawberries were stored in enclosed plastic trays to maintain a high relative humidity (about 95\%) and incubated at $20{ }^{\circ} \mathrm{C}$. Samples were taken at 0 , 1,2 , and 3 days after treatment. After removing the wound tissue with a sterile borer (6-mm-diameter and 5-mm-deep), the fresh tissue around the wound was picked up by another sterile borer (9-mmdiameter and 10-mm-deep). Two grams of the fresh tissue from six fruits were homogenized with $10 \mathrm{~mL}$ of cold $\left(4{ }^{\circ} \mathrm{C}\right) 50 \mathrm{mM}$ (pH 7.8) sodium phosphate buffer containing $1.33 \mathrm{mM}$ EDTA and $1 \%$ PVPP. The homogenates were then centrifuged at $12,000 \times g$ at $4{ }^{\circ} \mathrm{C}$ for $15 \mathrm{~min}$ and the supernatants were assayed. There were three replicates per treatment. The experiment was conducted twice. The testing methods of enzyme activities were described below.

PPO activity was measured as the method described by Aquino-Bolaños and Mercado-Silva [31] with some modifications, using catechol as a substrate. The reaction mixtures contained $2.9 \mathrm{~mL}$ of $0.1 \mathrm{M}$ catechol (prepared by $50 \mathrm{mM}$ sodium phosphate buffer, $\mathrm{pH} 6.4$, incubated at $30{ }^{\circ} \mathrm{C}$ for $5 \mathrm{~min}$ ) as a substrate and $100 \mu \mathrm{L}$ of enzymatic extract. The change in absorbance was read per minute at $398 \mathrm{~nm}$, and determined 3 min continuously. The PPO activity was expressed as U per $g$ of fresh tissue weight (U/g FW), which one unit (U) of PPO was defined as the change of absorbance ascent 0.01 in $1 \mathrm{~min}$.

POD activity was measured as the method described by Lurie et al. [24] with some modifications, using guaiacol as a substrate. The reaction mixture contained $0.2 \mathrm{~mL}$ of crude enzyme extract (supernatant extract), $2.2 \mathrm{~mL}$ of $0.3 \%$ guaiacol (prepared by $50 \mathrm{mM}$ sodium phosphate buffer, $\mathrm{pH}$ 6.4) and was incubated for $5 \mathrm{~min}$ at $30{ }^{\circ} \mathrm{C}$. The reaction was then initiated immediately by adding $0.6 \mathrm{~mL}$ of $0.3 \% \mathrm{H}_{2} \mathrm{O}_{2}$ (prepared by $50 \mathrm{mM}$ sodium phosphate, $\mathrm{pH} 6.4$, and incubated at $30{ }^{\circ} \mathrm{C}$ for $5 \mathrm{~min}$ ) and the activity was determined by measuring at $\mathrm{A}_{470}$ once every $1 \mathrm{~min}$ for $3 \mathrm{~min}$. A cuvette containing all components except adding $0.6 \mathrm{~mL}$ of distilled water was used as a control. The POD activity was expressed as $\mathrm{U}$ per $\mathrm{g}$ fresh tissue weight $(\mathrm{U} / \mathrm{g} \mathrm{FW})$. One unit was defined as an increase in $\mathrm{A}_{470}$ of 0.01 per minute.

$\beta$-1,3-glucanase was assayed by measuring the amount of reducing sugar released from the substrate by the method reported by Ippolito et al. [32] with some modifications. Crude enzyme sample of $250 \mu \mathrm{L}$ was routinely added to $250 \mu \mathrm{L}$ of $0.2 \%$ laminarin $(w / v)$ in $50 \mathrm{mM}, \mathrm{pH} 5.0$, and 
potassium acetate buffer and incubated at $37{ }^{\circ} \mathrm{C}$ for $1 \mathrm{~h}$. For the control, the same mixture was similarly diluted at zero incubation time. The reaction was stopped by adding $1.5 \mathrm{~mL}$ of 3, 5-dinitrosalicylate and boiling for $5 \mathrm{~min}$ on a water bath. And the amount of reducing sugars was measured spectrophotometrically at $500 \mathrm{~nm}$ using a UV-1601 spectrophotometer (Shimadzu, Japan). One unit of the $\beta$-1,3-glucanase was defined as the formation of $1 \mathrm{mg}$ glucose equivalents per hour and the specific activity was expressed as the $\mathrm{U}$ per gram $\mathrm{FW}$.

\subsection{Protein Sample Preparation}

Liquid cultures of the yeast were grown in NYDB or NYDB+ $0.5 \%$ trehalose, respectively as described above (Antagonist and growth conditions). The method of protein sample preparation was described by Li et al. [33] with some modifications. The yeast cells were harvested from NYDB or $\mathrm{NYDB}+0.5 \%$ trehalose by centrifuging at $10,000 \times g$ for $10 \mathrm{~min}\left(4^{\circ} \mathrm{C}\right)$ and washed three times with cold double-distilled water to remove residual medium. Then grind sample (yeast cells) into a fine powder in a mortar pestle under liquid nitrogen, a fine powder is important for effective contaminant removal and protein extraction. Transfer the powder into a $10-\mathrm{mL}$ tube, filled the tube with TE buffer containing $10 \mathrm{mM}$ Tris-HCL, pH 8.0, $1 \mathrm{mM}$ EDTA, and $1 \mathrm{mM}$ PMSF, incubated at $4{ }^{\circ} \mathrm{C}$ for $30 \mathrm{~min}$. Mixed well by vortexing, and take $0.5 \mathrm{~mL}$ to $1.5 \mathrm{~mL}$ EP tube, added $8.7 \mu \mathrm{L}$ of $10 \mathrm{mg} \mathrm{mL}^{-1} \mathrm{PMSF}$ and several $0.5 \mathrm{~mm}$ glass beads, vortex oscillator $5 \times 30 \mathrm{~s}$, and interval ice bath for $1 \mathrm{~min}$. Then added $25 \mu \mathrm{g}$ of RNase A and $100 \mu \mathrm{g}$ of DNase, incubated at $4{ }^{\circ} \mathrm{C}$ for $30 \mathrm{~min}$. Centrifuge at $15,000 \times g$ for $30 \mathrm{~min}\left(4^{\circ} \mathrm{C}\right)$, take the supernatant $400 \mu \mathrm{L}$, added three volumes of $20 \%$ TCA/acetone $\left(-20{ }^{\circ} \mathrm{C}\right.$ pre-cooled at least $30 \mathrm{~min}$ ), mixed well, incubated at $-20{ }^{\circ} \mathrm{C}$ for $12-16 \mathrm{~h}$. Centrifuge at $15,000 \times g$ for $30 \mathrm{~min}\left(4{ }^{\circ} \mathrm{C}\right)$, discard the supernatant, washed with acetone $\left(-20{ }^{\circ} \mathrm{C}\right.$ pre-cooled $)$ several times, and after washed every time, centrifuge at $15,000 \times g$ for $30 \mathrm{~min}\left(4^{\circ} \mathrm{C}\right)$, and discard the supernatant. Airdry at room temperature at least $10 \mathrm{~min}$ to remove residual acetone. Then solubilized in $100 \mu \mathrm{L}$ of thiourea/urea/lysis buffer containing $2 \mathrm{M}$ thiourea, $7 \mathrm{M}$ urea, 4\% (w/v) CHAPS, $65 \mathrm{mM}$ DTT, 0.2\% $(w / v)$ Bio-Lyte. Protein samples were kept at $-70^{\circ} \mathrm{C}$ until use. The protein concentration was determined according to Bradford's method using bovine serum albumin as standard [34].

\subsection{2-DE and Image Analysis}

Two-dimensional electrophoresis (2-DE) and image analysis were performed as described by Wang et al. [35]. $380 \mu \mathrm{g}$ of each protein extract was separated by iso-electrophoresis using IPG strips $(\mathrm{pH} 3-10,17 \mathrm{~cm})$ in the Protean system (Bio-Rad). The second dimension was run on a $12.5 \%$ polyacrylamide gel using the Multiphor system (Amersham Biosciences). Gels were visualized by Coomassie Blue staining. The stained gels were scanned and analyzed using PDQuest software (version 7.2, Bio-Rad, Hercules, CA, USA). Proteins that were increased 2-fold at least at one point after treatment, as well as exhibiting the same expression pattern among the replicates, were considered as significant and reproducible changes proteins. These proteins were subjected to identification. At least three biological replicates were performed for each treatment. 


\subsection{Protein In-gel Digestion}

Differentially expressed protein spots were excised from the gel and were washed twice by double-distilled $\mathrm{H}_{2} \mathrm{O}$, then destained with $50 \mathrm{mM} \mathrm{NH}_{4} \mathrm{CO}_{3}$ /acetonitrile solution. Washed with $25 \mathrm{mM}$ $\mathrm{NH}_{4} \mathrm{CO}_{3}, 50 \%$ acetonitrile and acetonitrile until the gels became full white, then vacuum drained 5 min. Added $2 \mu \mathrm{L} 10 \mu \mathrm{g} \cdot \mu \mathrm{L}^{-1}$ trypsin (Sigma-Aldrich, St Louis, MO, USA), incubated at $4{ }^{\circ} \mathrm{C}$ for $30 \mathrm{~min}$, then added $10 \mu \mathrm{L} 25 \mathrm{mM} \mathrm{NH}_{4} \mathrm{CO}_{3}$, the gels were incubated overnight at $37{ }^{\circ} \mathrm{C}$. The supernatant was collected for MS analysis [36].

\subsection{Protein Identification by MALDI-TOF/TOF and Database Query}

The peptide solution was analyzed using MALDI TOF/TOF mass spectrometer (Ultraflex III, Bruker-Daltonics). The resulting monoisotopic peptide masses were queried against protein database in NCBInr using MASCOT software [37] and the following search parameters: all entries, trypsin, up to one missed cleavage, carbamidomethyl $(\mathrm{C})$, oxidation $(\mathrm{M})$ and Gln-Pyro-glu, peptide tolerance 0.3 Dal, mass value $\mathrm{MH}^{+}$, and monoisotopic [38].

\subsection{Statistical Analysis}

The data were analyzed by the analysis of variance (ANOVA) in the statistical program SPSS/PC version II.x, (SPSS Inc. Chicago, Illinois, USA) and the Duncan's multiple range test was used for means separation. In addition, when the group of the data was two, the independent samples t test was applied for means separation. The statistical significance was assessed at the level $P=0.05$.

\section{Conclusions}

Our results showed that the antagonistic activity of $P$. carribbica to postharvest Rhizopus decay and gray mold decay of strawberries can be enhanced by adding trehalose in the media, which may offer great practical potential in reducing the postharvest diseases of strawberries. The mode of action may be involved in trehalose inducing incubation $P$. carribbica induce more defense enzymes such as PPO, $\mathrm{POD}$, and pothogenesis-related (PR) proteins such as $\beta-1,3$-glucanase of fruits, to improve disease resistance of strawberries. Identification of differentially expressed proteins showed the basic metabolism of $P$. carribbica was improved by trehalose induced incubation. These mechanisms need further study.

\section{Acknowledgements}

This research was supported by the Natural Science Foundation of Jiangsu Province (BK2009214), the Technology Support Plan of Jiangsu Province (BE2011395), the Foundation for the Eminent Talent of Jiangsu University, the Project Sponsored by the Scientific Research Foundation for the Returned Overseas Chinese Scholars, State Education Ministry, and the Project Funded by the Priority Academic Program Development of Jiangsu Higher Education Institutions. 


\section{References}

1. Romanazzi, G.; Nigro, F.; Ippolito, A.; Salerno, M. Effect of short hypobaric treatments on postharvest rots of sweet cherries, strawberries and table grapes. Postharvest Biol. Technol. 2001, $22,1-6$.

2. Wszelaki, A.L.; Mitcham, E.J. Effect of combinations of hot water dips, biological control and controlled atmospheres for control of gray mold on harvested strawberries. Postharvest Biol. Technol. 2003, 27, 255-264.

3. Norman, C. EPA sets new policy on pesticide cancer risks. Science 1988, 242, 366-367.

4. Wisniewski, M.E.; Wilson, C.L. Biological control of postharvest diseases of fruits and vegetables: recent advance. HortScience 1992, 27, 94-98.

5. Peng, G.; Sutton, J.C. Evaluation of microorganisms for biocontrol of Botrytis cinerea in strawberry. Can. J. Plant Pathol. 1991, 13, 247-257.

6. Swadling, I.R.; Jeffries, P. Isolation of microbial antagonists for biocontrol of grey mould disease of strawberries. Biocontrol Sci. Technol. 1996, 6, 125-136.

7. Lima, G.; Ippolito, A.; Nigro, F.; Salerno, M. Effectiveness of Aureobasidium pullulans and Candida oleophila against postharvest strawberry rots. Postharvest Biol. Technol. 1997, 10, 169-178.

8. Guinebretiere, M.H.; Nguyen-The, C.; Morrison, N.; Reich, M.; Nicot, P. Isolation and characterization of antagonists for the biocontrol of the postharvest wound pathogen Botrytis cinerea on strawberry fruits. J. Food Protect. 2000, 63, 386-394.

9. Zhang, H.Y.; Wang, L.; Dong, Y.; Jiang, S.; Cao, J.; Meng, R.J. Postharvest biological control of gray mold decay of strawberry with Rhodotorula glutinis. Biol. Control 2007, 40, 287-292.

10. Droby, S.; Wsiniewski, M.; Ei-Ghaouth, A.; Wilson, C. Biological control of postharvest diseases of fruit and vegetables: Current achievements and future challenges. Acta Hortic. 2003, 628, 703-713.

11. Sharma, R.R.; Singh, D.; Singh, R. Biological control of postharvest diseases of fruits and vegetables by microbial antagonists: A review. Biol. Control 2009, 50, 205-221.

12. Yu, T.; Wang, L.P.; Yin, Y.; Wang, Y.X.; Zheng, X.D. Effect of chitin on the antagonistic activity of Cryptococcus laurentii against Penicillium expansum in pear fruit. Int. J. Food Microbiol. 2008, 122, 44-48.

13. Ge, L.L.; Zhang, H.Y.; Chen, K.P.; Ma, L.C.; Xu, Z.L. Effect of chitin on the antagonistic activity of Rhodotorula glutinis against Botrytis cinerea in strawberries and the possible mechanisms involved. Food Chem. 2010, 120, 490-495.

14. Schiraldi, C.; Lernia, I.D.; Rosa, M.D. Trehalose production: exploiting novel approaches. Trends Biotechnol. 2002, 20, 420-425.

15. Mazzobre, M.F.; Buera, M.D.P. Combined effects of trehalose and cations on the thermal resistance of beta-galactosidase in freeze-dried systems. BBA-Gen. subjects 1999, 1473, 337-344.

16. Crowe, J.H.; Crowe, L.M.; Chapman, D. Preservation of membrane in anhydrobiotic organism: the role of trehalose. Science 1984, 223, 701-703.

17. Gancedo, C.; Flores, C.L. The importance of a functional trehalose biosynthetic pathway for the life of yeasts and fungi. FEMS Yeast Res. 2004, 4, 351-359. 
18. Li, B.Q.; Zhou, Z.W.; Tian, S.P. Combined effects of endo- and exogenous trehalose on stress tolerance and biocontrol efficacy of two antagonistic yeasts. Biol. Control 2008, 46, 187-193.

19. Richards, A.B.; Krakowka, S.; Dexter, L.B.; Schmidd, H.; Wolterbeeke, A.P.M.; Waalkens-Berendsene, D.H.; Shigoyuki, A.; Kurimotof, M. Trehalose: a review of properties, history of use and human tolerance, and results of multiple safety studies. Food Chem. Toxicol. 2002, 40, 871-898.

20. Mayer, A.M.; Harel, E. Polyphenol oxidases in plants. Phytochemistry 1979, 18, 193-215.

21. Jung, W.J.; Jin, Y.L.; Kim, Y.C.; Kim, K.Y.; Park, R.D.; Kim, T.H. Inoculation of Paenibacillus illinoisensis alleviates root mortality, activates of lignification-related enzymes, and induction of the isozymes in pepper plants infected by Phytophthora capsici. Biol. Control 2004, 30, 645-652.

22. Mohammadi, M.; Kazemi, H. Changes in peroxidase and polyphenol oxidase activities in susceptible and resistant wheat heads inoculated with Fusarium graminearum and induced resistance. Plant Sci. 2002, 162, 491-498.

23. Passardi, F.; Penel, C.; Dunand, C. Performing the paradoxical: how plant peroxidases modify the cell wall. Trends Plant Sci. 2004, 9, 534-540.

24. Lurie, S.; Fallik, E.; Handros, A.; Shapira, R. The possible involvement of peroxidase in resistance to Botrytis cinereain heat treated tomato fruit. Physiol. Mol. Plant P. 1997, 50, 141-149.

25. Yu, T.; Zheng, X.D. Salicylic acid enhances biocontrol efficacy of the antagonist Cryptococcus laurentii in apple fruit. J. Plant Growth Regul. 2006, 25, 166-174.

26. Joosten, M.H.A.J.; Verbakel, H.M.; Nettekoven, M.E.; van Leeuwen, J.; van der Vossen, R.T.M.; de Wit, P.J.G.M. The phytopathogenic fungus Cladosporium fulvum is not sensitive to the chitinase and $\beta$-1,3-glucanase defence proteins of its host, tomato. Physiol. Mol. Plant P. 1995, 46, 45-59.

27. Charles, M.T.; Tano, K.; Asselin, A.; Arul, J. Physiological basis of UV-C induced resistance to Botrytis cinerea in tomato fruit. V. Constitutive defence enzymes and inducible pathogenesisrelated proteins. Postharvest Biol. Technol. 2009, 51, 414-424.

28. Qin, G.Z.; Tian, S.P.; Xu, Y.; Wan, Y.K. Enhancement of biocontrol efficacy of antagonistic yeasts by salicylic acid in sweet cherry fruit. Physiol. Mol. Plant Pathol. 2003, 62, 147-154.

29. Kurtzman, C.P.; Fell, J.W. Definition, Classification and Nomenclature of the Yeasts. In The Yeasts, 4th ed.; CBS-Fungal Biodiversity Centre: Utrecht, The Netherlands, 1998; pp. 3-5.

30. Li, S.S.; Cheng, C.; Li, Z.; Chen, J.Y.; Yan, B.; Han, B.Z.; Reeves, M. Yeast species associated with wine grapes in China. Int. J. Food Microbiol. 2010, 138, 85-90.

31. Aquino-Bolaños, E.N.; Mercado-Silva, E. Effects of polyphenol oxidase and peroxidase activity, phenolics and lignin content on the browning of cut jicama. Postharvest Biol. Technol. 2004, 33, $275-283$.

32. Ippolito, A.; EI-Ghaouth, A.; Wilson, C.L.; Wisniewski, M. Control of postharvest decay of apple fruit by Aureobasidium pullulans and induction of defense responses. Postharvest Biol. Technol. 2000, 19, 265-272.

33. Li, B.Q.; Lai, T.F.; Qin, G.Z.; Tian, S.P. Ambient pH Stress Inhibits Spore Germination of Penicillium expansum by Impairing Protein Synthesis and Folding: A Proteomic-Based Study. J. Proteome Res. 2010, 9, 298-307. 
34. Bradford, M.M. A rapid and sensitive method for the quantitation of microgram quantities of protein utilizing the principle of protein-dye binding. Anal. Biochem. 1976, 72, 248-254.

35. Wang, Y.; Yang, L.M.; Xu, H.B.; Li, Q.F.; Ma, Z.Q.; Chu, C.G. Differential proteomic analysis of proteins in wheat spikes induced by Fusarium graminearum. Proteomics 2005, 5, 4496-4503.

36. Zhang, L.; Yu, Z.F.; Jiang, L.; Jiang, J.; Luo, H.B.; Fu, L.R. Effect of post-harvest heat treatment on proteome change of peach fruit during ripening. J. Proteomics 2011, 74, 1135-1149.

37. Matrixscience Home Page. http://www.matrixscience.com (accessed on 21 March 2012).

38. Majoul, T.; Bancel, E.; Tribol, E.; Hamida, J.B.; Branlard, G. Proteomic analysis of the effect of heat stress on hexaploid wheat grain: Characterization of heat-responsive proteins from total endosperm. Proteomics 2003, 3, 175-183.

(C) 2012 by the authors; licensee MDPI, Basel, Switzerland. This article is an open access article distributed under the terms and conditions of the Creative Commons Attribution license (http://creativecommons.org/licenses/by/3.0/). 